\title{
DONALD TRUMP DAN REORIENTASI KEBIJAKAN KEAMANAN AMERIKA SERIKAT TERHADAP PROGRAM PENGEMBANGAN SENJATA NUKLIR KOREA UTARA
}

\author{
Muhammad Najeri Al Syahrin ${ }^{1}$ \\ ${ }^{1}$ Universitas Muhammadiyah Kalimantan Timur \\ Email: najeri_alsyahrin@umkt.ac.id
}

\begin{abstract}
ABSTRAK
Penelitian ini mengidentifikasi beberapa kecenderungan perubahan orientasi kebijakan keamanan Amerika Serikat di bawah kepemimpinan Donald Trump terhadap program pengembangan senjata nuklir Korea Utara. Identifikasi tersebut diawali dengan penjelasan beberapa kebijakan yang sudah dilakukan oleh PresidenPresiden Amerika Serikat sebelumnya dalam upaya untuk menghentikan program pengembangan nuklir Korea Utara. Tulisan ini juga memprediksi kebijakan keamanan yang tepat dan efektif dalam upaya denuklirisasi semenanjung Korea. Kebijakan Trump diharapkan bisa menunjukkan urgensi yang lebih besar daripada kebijakan Presiden Amerika Serikat sebelumnya. Berdasarkan asumsi tersebut, melalui strategi "Maximum Pressure and Engagement" Trump berupaya merubah arah kebijakan (reorientasi) terhadap kebijakan yang selama ini sudah dilakukan Presiden Amerika Serikat sebelumnya. Dalam strategi tersebut, Trump mengkombinasikan antara strategi Hard Power Presiden Bush dan Soft Power Presiden Obama menjadi Smart Power. Kebijakan ini mengkombinasikan semua sarana dan solusi diplomatik, sanksi, pemotongan sumber ekonomi, penghentian pasokan pangan, diplomasi isolasi dan perundingan. Strategi ini diharapkan efektif untuk memaksa Pyongyang untuk memilih antara pengembangan senjata nuklir atau kelangsungan hidupnya sebagai sebuah negara.
\end{abstract}

Kata kunci: kebijakan keamanan; senjata nuklir; strategi maximum pressure and engagement

\begin{abstract}
This article identifies some of the trends of change in the orientation of United States security policy under Donald Trump's leadership toward North Korea's nuclear weapons development program. The identification begins with an explanation of some of the policies already made by previous US Presidents in an effort to stop North Korea's nuclear development program. This article also predicts the appropriate and effective security policies in the denuclearization of the Korean peninsula. Trump's policy is expected to show greater urgency than the policies of the previous President of the United States. Under this assumption, Trump's "Maximum Pressure and Engagement" strategy seeks to reorientation the policies that have been done by the President of the United States before In that strategy, Trump combines President Bush's Hard Power and President Obama's Soft Power strategy into Smart Power strategy. This policy combines all diplomatic means and solutions, sanctions, cuts in economic resources, cessation of food supplies, isolation diplomacy and negotiations. This strategy is expected to be effective in forcing Pyongyang to choose between nuclear weapons development or its survival as a country.
\end{abstract}

Keywords: security policy; nuclear weapons; maximum pressure and engagement strategy

\section{Pendahuluan}

Pengembangan senjata nuklir merupakan permasalahan yang sangat penting bagi stabilitas keamanan kawasan selama dua dekade terakhir. Asia Timur merupakan salah satu kawasan yang paling rentan akan bahaya nuklir. Permasalahan nuklir Korea Utara telah menjadi ancaman tidak hanya bagi keamanan negara-negara di kawasan Asia Timur saja, tetapi juga negara diluar kawasan tersebut. Amerika Serikat sebagai negara yang berpengaruh dalam geopolitik dan 
geostrategi global diharapkan bisa menerapkan kebijakan yang mempertahankan stabilitas keamanan kawasan Asia Timur. Hal ini tentu memberikan tantangan bagi Presiden Donald Trump, dalam memainkan peranannya sebagai negara adidaya yang memiliki pengaruh di kawasan Asia Timur. Sejalan dengan perubahan yang terus terjadi dibawah kepemimpinan Trump, Semenanjung Korea selalu menawarkan tantangan bagi kepentingan keamanan Amerika Serikat di kawasan Asia Timur. Di satu sisi, Korea Selatan telah mengembangkan kapasitas, meningkatkan kemampuan militer dan memungkinkan kerja sama yang lebih aktif dengan Amerika Serikat dalam upaya menjaga kepentingan keamanan masing-masing negara di kawasan Asia Timur. Di sisi lain, rezim otoriter Korea Utara telah memperluas kemampuan nuklirnya dengan terus melakukan pengembangan rudal kendali jarak jauh dan secara langsung telah mengancam kepentingan Amerika Serikat di kawasan Asia Timur. ${ }^{1}$

Kebijakan kawasan Asia Timur akan menjadi salah satu kebijakan keamanan yang penting bagi Amerika Serikat dalam beberapa tahun kedepan. Tentu kebijakan ini akan secara hati-hati dirumuskan, dan sejauh mana perubahan yang akan terjadi pada kebijakan Amerika Serikat di bawah Trump apabila dibandingkan dengan strategi Poros Pasifik yang sudah dijalankan oleh Presiden Obama sebelumnya. Perhatian kini tertuju pada karakter pribadi Trump yang kontroversial. Dalam beberapa kesempatan, Trump kerap menyuarakan perbedaan mencolok dengan tradisi kebijakan luar negeri Amerika Serikat selama ini. Ia mendukung penggunaan senjata nuklir bagi Korea Selatan dan Jepang. Trump juga sering memberikan pernyataan 'sarkastik' terhadap Cina dan Korea Utara, baik yang diungkapkan melalui kicauan Twitter maupun media massa secara langsung sehingga semakin memperkeruh keadaan. Trump juga melontarkan

1 C.L. Pritchard \& J.H. Tilelli, Jr., U.S. Policy Toward the Korean Peninsula. New York: Council on Foreign Relations. 2010. pernyataan bahwa opsi militer akan memungkinkan untuk digunakan Amerika Serikat dalam menangani permasalahan nuklir Korea Utara. Hal ini tentu saja menimbulkan perdebatan sengit. Jepang, Korea Selatan dan Cina tentu tidak menginginkan opsi penggunaan kekuatan militer terhadap Korea Utara karena akan mengakibatkan perang di kawasan. Opsi militer juga pasti akan memberikan dampak luas tidak hanya di kawasan Asia Timur tetapi juga kawasan Asia secara umum. Sejauh mana Trump bisa menyiasati keadaan di kawasan tanpa menggunakan kekuatan militer tentu menjadi pembahasan yang menarik.

Berdasarkan paparan tersebut tulisan ini ingin memaparkan bagaimana perubahan arah kebijakan keamanan Amerika Serikat terhadap program nuklir Korea Utara selama kepemimpinan Donald Trump apabila dibandingkan dengan kebijakan-kebijakan Amerika Serikat sebelumnya. Lebih jauh, tulisan ini juga akan menganalisis efektivitas strategi yang akan digunakan Trump untuk menghentikan program nuklir Korea Utara, yang mana telah gagal dilakukan oleh PresidenPresiden Amerika Serikat sebelumnya. Dalam konteks ini, tentu akan sangat menarik untuk menganalisis berbagai kemungkinan strategi dan kebijakan yang akan diambil oleh Trump, apakah pilihan kebijakan militer akan menjadi kebijakan prioritas Amerika Serikat dan sejauh mana kebijakan tersebut menyimpang dari kebijakan-kebijakan yang selama ini sudah dilakukan Presiden Amerika Serikat sebelumnya.

\section{Refleksi Kebijakan Keamanan Amerika Serikat Era Clinton, Bush, dan Obama}

Selama lebih dari 25 tahun kebijakan keamanan Amerika Serikat dan pendekatan diplomatik yang dilakukan telah mengalami kegagalan dalam upaya membujuk Korea Utara untuk menghentikan program nuklirnya. Dalam beberapa dekade, Amerika Serikat selalu mengupayakan kesepakatan dengan rezim Korea Utara dalam rangka untuk menjaga kepentingannya di kawasan. Pada masa pemerintahan Bill Clinton, Amerika Serikat 
99 Muhammad Najeri Al Syahrin | Donald Trump dan Reorientasi Kebijakan Keamanan Amerika Serikat terhadap Program Pengembangan Senjata Nuklir Korea Utara

pada 21 Oktober 1994 mencoba membujuk Korea Utara dengan Geneva Agreed Framework tetapi tidak berhasil. Kesepakatan ini menyatakan bahwa Korea Utara akan menonaktifkan reaktor nuklir dan sebagai konsekuensinya, Amerika Serikat dan Korea Selatan akan menjamin kebutuhan energi dan menyediakan bahan bakar minyak untuk Korea Utara. ${ }^{2}$ Jepang dan Korea Selatan juga akhirnya menyatakan secara aktif ikut berpartisipasi dalam program ini, yang kemudian secara resmi berkembang menjadi Korea Peninsula Energy Organizations (KEDO) pada tahun 1995. Pada kenyataannya, Geneva Agreed Framework maupun KEDO bukanlah hanya kesepakatan untuk memberikan bantuan keuangan dan energi kepada Korea Utara, tetapi juga bertujuan politik untuk mencegah perkembangan senjata nuklir Korea Utara dan membuka dialog politik dengan rezim Korea Utara. ${ }^{3}$

KEDO dianggap Amerika Serikat tidak memberikan hasil yang efektif dalam upaya menghentikan program pengembangan senjata nuklir Korea Utara. Pada tanggal 17 April 1996, Amerika Serikat dan Korea Selatan mengusulkan diadakannya Four Power Talks antara Amerika Serikat, Cina, Korea Selatan dan Korea Utara. Pertemuan empat pihak ini akhirnya berlangsung pada Desember 1997 di Jenewa. Dalam kesempatan itu, Korea Utara kembali menegaskan bahwa Amerika Serikat harus menarik seluruh pasukan militernya di Semenanjung Korea. Memang tidak banyak terobosan berarti dalam kerangka perjanjian ini dan belum terdapat agenda yang jelas untuk pertemuan selanjutnya. $^{4}$

Ketika George Bush terpilih sebagai Presiden Amerika Serikat pada tahun 2000, kebijakan Amerika Serikat terhadap program

\footnotetext{
${ }^{2}$ G.J. Moore, America's Failed North Korea Nuclear Policy: A New Approach. Asian Perspective. Vol 32, no. 4, pp. 11-12. 2008.

${ }^{3}$ C.K. Armstrong, US-North Korean Relations. In Feffer, J (Ed.), the Future of US-Korean Relations (pp. 13). London: Routledge. 2006.

${ }^{4}$ D. Wirengjurit, Kawasan Damai dan Bebas Senjata Nuklir: Pengertian, Sejarah, dan Perkembangannya. Bandung: Alumni. 2002.
}

nuklir Korea Utara mengalami beberapa perubahan drastis. Agreed Framework yang disepakati tahun 1994 tidak lagi digunakan sebagai kerangka kerja utama terkait hubungan antara kedua negara dalam permasalahan nuklir. Pemerintahan Bush juga melakukan tinjauan ulang terhadap kebijakan pada masa pemerintahan Bill Clinton. Ketika Presiden Korea Selatan Kim Dae Jung, mengunjungi Washington pada Maret 2001, Presiden Bush menyatakan sunshine policy yang selama ini dilakukan oleh Korea Selatan sudah tidak efektif digunakan dalam menghadapi permasalahan nuklir Korea Utara. Korea Utara dinilai tidak mempunyai komitmen yang kuat terhadap kesepakatan dalam sunshine policy. Penilaian Amerika Serikat ini menjadi sebuah keputusan yang dilematis bagi Korea Selatan, yang selama ini menganggap sunshine policy sebagai sebuah kebijakan non-militer yang efektif dalam menghadapi rezim Korea Utara. Di sisi yang lain, segala kebijakan Korea Selatan terkait permasalahan nuklir Korea Utara juga harus mendapat dukungan dari Amerika Serikat. ${ }^{5}$

Pemerintah Bush kemudian mengadopsi pendekatan yang sangat berbeda dan cenderung sulit untuk kembali diterapkan, yaitu dengan intens melakukan tekanan terhadap Korea Utara dan mengkategorikannya sebagai bagian dari "negara poros setan". Selain itu, semasa pemerintahan George W. Bush, Amerika Serikat juga terlibat aktif sejak tahun 2003 dalam Six Party Talks, yang dalam perjalananya juga tidak memberikan hasil yang efektif dalam upaya denuklirisasi Semenanjung Korea. ${ }^{6}$

Pada tahun 2008, pemerintahan Obama kemudian melakukan pendekatan yang berbeda dengan yang dilakukan presiden Amerika Serikat sebelumnya yaitu melalui pendekatan smart power dalam strategi Poros Pasifik (Pivot Pacific), pendekatan dengan tetap melakukan tekanan (pressure) namun disisi lain memberikan peluang bagi perundingan negosiasi nuklir untuk Korea Utara, namun hasilnya

\footnotetext{
${ }^{5}$ Moore, op. cit., p. 12.

${ }^{6}$ Pritchard \& Tilelli, op. cit., p. 6.
} 
100 Muhammad Najeri Al Syahrin | Donald Trump dan Reorientasi Kebijakan Keamanan Amerika Serikat terhadap Program Pengembangan Senjata Nuklir Korea Utara

kemudian tidak lebih baik dari kebijakankebijakan sebelumnya. Korea Utara masih enggan dalam menghentikan kemampuan nuklirnya dan kemudian melakukan empat kali uji coba nuklir di bawah pemerintahan Obama (tahun 2009, 2013, dan dua uji coba terjadi di awal tahun 2017). Kita mungkin tidak setuju dan melakukan perdebatan mengenai pendekatan apa yang tepat untuk dilakukan, tetapi fakta yang terjadi, semua strategi yang sudah dilakukan oleh Presiden Amerika Serikat terkait dengan program nuklir Korea Utara sejak Perang Dingin sampai kini terbukti tidak efektif.?

Di antara banyak analisis yang muncul tentang kebijakan keamanan Pemerintahan Trump di kawasan Asia Timur, terdapat hal yang paling ditekankan, yaitu sejauh mana kebijakan tersebut akan "menyimpang" dari kebijakan Presiden sebelumnya. Tanda-tanda akan terjadinya perubahan kontras terhadap kebijakan keamanan yang Amerika Serikat anut selama ini sudah terlihat dari pernyataan Trump sejak masa kampanye, ia secara langsung menyatakan akan merubah arah dan strategi kebijakan keamanan Amerika Serikat. Melalui berbagai pertimbangan keamanan, ekonomi, dan politik kiranya pemerintahan Trump akan terus melihat arti strategis kepentingan Amerika Serikat di kawasan Asia Timur secara luas. ${ }^{8}$

\section{Amerika Serikat, Cina dan Aliansi Trilateral}

Dalam penyusunan kebijakan keamanan di kawasan Asia Timur, Amerika Serikat selalu mempertimbangan keikutsertaan dan kerja sama strategis antara Amerika Serikat, Korea Selatan dan Jepang. Permasalahan Semenanjung Korea dianggap sebagai permasalahan penting dan paling mengancam bagi keamanan dan kepentingan negara-negara tersebut. Keterlibatan aktif Cina juga diharapkan bisa memberikan dampak positif, namun pada

\footnotetext{
${ }^{7}$ B. Courmont, Trump's Foreign Policy: Implications for Europe and East Asia, Iris: Institut De Relations Internationales Et Strategiques, Policy Brief, pp. 4. 2016.

8 M. Lanteigne, A Pivot to What? Asia-Pacific Foreign Policy under Trump, Norwegian Institute of International Affairs, Policy Brief, p. 7. 2016.
}

kenyataannya Cina selalu memiliki peran ganda. Beijing mendapati dirinya terperangkap dalam dilema kepentingan strategis dalam mencegah nuklir Korea Utara. Karena itulah, Beijing mendukung sanksi yang diberikan Dewan Keamanan PBB terhadap Korea Utara namun di sisi lain, Beijing juga tetap melakukan kendali terhadap rezim Korea Utara. Cina akan menghadapi konsekuensi serius bagi kepentingan regionalnya apabila rezim Korea Utara berakhir. Persepsi Cina terhadap permasalahan Korea Utara terkesan sangat apatis. Cina tidak memberi indikasi kuat bahwa pihaknya bersedia untuk mengurusi masalah keamanan Pyongyang. Surat kabar pemerintah China Global Times mengatakan bahwa Cina tidak akan membantu Korea Utara dan bersikap netral jika ia melakukan serangan militer terhadap Amerika Serikat dan sekutunya. ${ }^{9} \mathrm{Di}$ sisi yang lain, ketakutan Cina apabila rezim Kim runtuh, akan mengirim jutaan pengungsi Korea Utara ke Cina. Ini adalah sesuatu yang secara tegas tidak diinginkan oleh Beijing. Setiap perubahan di Semenanjung Korea, dapat menyebabkan masalah bagi pemerintah Cina. Ditambah lagi, jika Amerika Serikat memenangkan perang dengan Korea Utara, maka negosiasi penyatuan kembali Semenanjung Korea akan sangat mungkin terjadi. Itu tidak hanya secara politis buruk bagi kepentingan Cina, tapi juga dari sisi keamanan akan sangat berpengaruh, khususnya keamanan perbatasan Cina dan Korea Utara. ${ }^{10}$

Masih sulit bagi Cina untuk menemukan jalan keluar yang terbaik dari dilema tersebut. Sehingga sangat rasional ia kemudian hanya bersikap apatis. Cina dalam beberapa tahun ke depan akan terus mempertahankan kepentingan

9 P. Sturm, “Opinion: Unlike Donald Trump, North Korea Has a Plan.” Deutsche Welle. 8 Agustus, 2017. Diakses dari http://www.dw.com/en/opinion-unlikedonald-trump-north-korea-has-a-plan/a-40059106 pada 23 Oktober 2017.

10 A. Ward, "The frightening New Developments in Trump's Standoff with North Korea." Vox. 1 Agustus, 2017.2 Diakses dari https://www.vox.com/world/2017/8/1/16068716/nort h-korea-icbm-missile-test-bomber-south-korea-japan pada 24 Oktober 2017. 
101 Muhammad Najeri Al Syahrin | Donald Trump dan Reorientasi Kebijakan Keamanan Amerika Serikat terhadap Program Pengembangan Senjata Nuklir Korea Utara

nuklir Korea Utara tersebut sebagai alat diplomasi sensitif untuk menekan kepentingan Amerika Serikat di kawasan. Masa depan hubungan Cina dan Amerika Serikat sebagian besar terletak pada keseimbangan kekuasaan ekonomi antara kedua negera tersebut. Dan kini terbukti, bahwa akselerasi pertumbuhan ekonomi Cina lebih cepat daripada yang diperkirakan. Perekonomian Cina tumbuh 6,8\% pada kuartal ketiga tahun 2017 ini, sedikit di bawah periode sebelumnya, namun masih di atas target awal pemerintah. ${ }^{11}$ Walaupun Amerika Serikat masih dianggap sebagai negara adidaya tunggal yang sangat berpengaruh, keberadaan Cina tentu juga tidak bisa diremehkan. Munculnya kekuatan baru Cina akan merubah konstelasi global kedepan dan tentu saja diharapkan Cina juga bisa memainkan peran penting didalamnya. ${ }^{12}$

Dalam beberapa tahun ini, kebijakan One Belt One Road (OBOR) juga secara umum merubah konstelasi kebijakan Cina. Investasi ambisius ini akan memperkuat strategi geoekonomi dan geopolitik Cina untuk menghubungkan benua Asia dan Eropa. Ambisi Cina dalam kebijakan OBOR adalah menjadikan Eurasia sebagai satu entitas ekonomi tunggal dibawah kendali Cina. Terdapat kepentingan geopolitik jangka panjang Cina dengan "mengikat" negara-negara di kawasan tersebut dalam sistem bisnis dan perdagangan bersama. Dengan melakukan investasi infrastruktur ini, Cina berusaha untuk merajut ekonomi Eropa dan Asia bersama-sama di sepanjang koridor perdagangan yang sudah lama terbengkalai ini. ${ }^{13}$ Posisi strategis dan kepemimpinan Cina dalam kawasan Eurasia melalui kebijakan OBOR ini

\footnotetext{
11 China Economic Review. China's third-quarter economic growth at $6.8 \%$. China Economic Review. 1 Oktober 2017. Diakses dari http://www.chinaeconomicreview.com/chinas-thirdquarter-economic-growth-68 pada 24 Oktober 2017. ${ }^{12}$ Courmont, op. cit., pp. 4.

13 A. Holland, "China's One Belt, One Road: An Ambitious Strategy Challenging the U.S." American Security Project. 18 Mei 2017. Diakses dari https://www.americansecurityproject.org/chinas-onebelt-one-road-an-ambitious-strategy-challenging-theu-s/ pada 25 Oktober 2017.
}

jelas akan memberikan implikasi yang besar bagi hubungan keamanan Amerika Serikat dengan Cina dalam beberapa tahun kedepan.

Dalam konteks ini, posisi hubungan Cina dengan Amerika Serikat sebagai negara yang berpengaruh di kawasan akan memiliki pengaruh penting dalam proses penyelesaian nuklir di Semenanjung Korea. Dalam kondisi yang berbeda, hubungan antara Amerika Serikat dan Cina bisa menuju ke arah yang lebih kondusif ketika terdapat ketergantungan ekonomi yang meningkat satu sama lainnya. Namun, Trump masih menilai Cina merupakan salah satu pesaing strategis bagi kepentingannya, utamanya di Asia Timur, sehingga ia harus dirangkul dalam sebuah hubungan yang menguntungkan dan bukan berisikan ketegangan. Cina sendiri berharap bahwa hubungan dengan negara-negara sekitar dan kekuatan utama dunia seperti Amerika Serikat dapat terus terjalin stabil. Terdapat beberapa kalangan yang optimis bahwa hubungan ekonomi antar kedua negara kekuatan utama di dunia ini, dengan segala kendala dan kemajuannya, akan berdampak positif bagi dunia internasional.

Hubungan ekonomi yang harmonis antara Amerika Serikat dengan Cina akan mempengaruhi kemakmuran jangka panjang masyarakat internasional. Meski demikian, hambatan dalam hubungan kedua negara ini akan tetap ada dan tidak akan menghilang secara otomatis. Asumsi ini akan diyakini akan tetap bertahan serta membuat Cina dan Amerika Serikat berada dalam hubungan yang kompleks dan penuh dengan kontradiksi. ${ }^{14}$ Selain terhadap Cina, kebijakan keamanan Amerika Serikat memiliki potensi untuk mempengaruhi beberapa kekuatan Asia Timur lainnya, termasuk sekutu Amerika Serikat di kawasan. Banyak reaksi negatif terhadap saran yang diberikan Trump bahwa Jepang dan Korea Selatan agar mempertimbangkan untuk memiliki senjata nuklir. Selain itu, Trump juga akan melakukan

\footnotetext{
${ }^{14}$ N.R. Yuliantoro, Menuju Kekuatan Utama Dunia: Sekilas Politik Luar Negeri Cina. Yogyakarta: Institute of International Studies. 2012.
} 
102 Muhammad Najeri Al Syahrin | Donald Trump dan Reorientasi Kebijakan Keamanan Amerika Serikat terhadap Program Pengembangan Senjata Nuklir Korea Utara

reorientasi kebijakan tentang kehadiran personil militer Amerika Serikat di kawasan. Jepang dan Korea Selatan yang secara khusus dianggap oleh Trump sebagai negara yang terlalu mengandalkan Amerika Serikat. ${ }^{15}$

Selain permasalahan hubungan Amerika Serikat dengan negara-negara di kawasan Asia Timur, sangat penting juga untuk mengetahui bagaimana kebijakan luar negeri Korea Utara terhadap Amerika Serikat. Kebijakan keamanan Korea Utara akan sangat mempengaruhi orientasi kebijakan keamanan Trump. Kebijakan luar negeri Korea Utara terhadap Amerika Serikat telah dibentuk oleh pengalaman pahit sejak Perang Korea dan persaingan antara Amerika Serikat dengan Uni Soviet pada masa Perang Dingin. Korea Utara menilai Amerika Serikat telah menggagalkan upaya Kim Il Sung untuk menyatukan Korea Selatan dengan Korea Utara melalui agresi militer pada masa Perang Korea. Selain itu, selama Perang Korea berlangsung, Korea Utara merupakan pihak yang selalu mengalami tekanan politik dan militer dari Amerika Serikat akibat kemampuan militer yang tidak seimbang antara Korea Utara dan Amerika Serikat. Pada masa Perang Korea, Amerika Serikat juga meluluhlantahkan infrastruktur di Korea Utara dengan bom udara selama masa perang. Operasi pemboman ini dan pengalaman masa lalu kemudian menjadi alasan kuat bagi Korea Utara untuk selalu mewaspadai ancaman Amerika Serikat bagi keamanan nasionalnya dan secara tidak langsung membentuk fenomena anti-Amerika di Korea Utara. Oleh karena itu, penggunaan nuklir sebagai strategi keamanan nasional merupakan alasan yang mendasari Korea Utara mengingat faktor sejarah yang menggambarkan adanya ancaman dan dominasi dari Amerika Serikat. ${ }^{16}$

\footnotetext{
15 M. Fisher, "What Is Donald Trump's Foreign Policy?" The New York Times. 2016. Diakses dari http://www.nytimes.com/2016/11/12/world/whatisdonald-trumps-foreign-policy.html pada 11 November 2016.

16 D.A. Pinkston, North Korea's Foreign Policy Towards the United States. Strategic Insights 5, no. 7, 23. 2006.
}

Selama masa Perang Dingin, Korea Utara masih keras menentang Amerika Serikat, yang digambarkan sebagai kekuatan penggerak di belakang eksploitasi imperialisme dan kapitalisme internasional. Pandangan tersebut ditambah lagi dengan pengalaman dan kebencian yang mendalam atas campur tangan Amerika Serikat dalam Perang Korea. Sasaran utama kebijakan strategis Korea Utara terhadap Amerika Serikat adalah untuk mencegah ancaman yang ditimbulkan akibat hubungan aliansi pertahanan antara Amerika Serikat dengan Korea Selatan. Aliansi tersebut secara tidak langsung akan memperkuat militer Korea Selatan dan hal itu tentu saja membahayakan bagi Korea Utara.

Dalam menghadapi Korea Utara Amerika Serikat memiliki opsi untuk menggunakan jalur diplomasi dan opsi militer. Apabila dipilih instrumen diplomasi, akan muncul dua kesulitan. Pertama, format perundingan. Amerika Serikat dan Korea Utara masih belum bersepakat apakah perundingan bersifat bilateral, multilateral, atau perundingan kawasan. Kedua, substansi perundingan. Mereka berbeda pandangan apakah perundingan bersifat komprehensif atau parsial. Amerika Serikat pada dasarnya menginginkan pengembangan senjata nuklir Korea Utara dapat diverifikasi dan kemudian disepakati melalui perundingan multilateral. Sebagai timbal balik, Amerika Serikat dan sekutunya bersedia memberikan bantuan ekonomi. Amerika Serikat mendesak Korea Utara untuk menghentikan program nuklirnya, baru kemudian konsensi ekonomi diberikan. Pola seperti ini pernah dijalankan pada masa pemerintahan Clinton, namun sulit untuk diimplementasikan secara efektif karena tidak adanya kepercayaan yang kuat antara Amerika Serikat dan Korea Utara. ${ }^{17}$

Sebaliknya, Korea Utara berpandangan bahwa penghancuran senjata nuklir harus

\footnotetext{
17 A.A. Sriyono, Korea Utara: Antara Diplomasi dan Perang dalam Sriyono, A.A dkk (Ed.), Hubungan Internasional: Percikan Pemikiran Diplomat Indonesia (p. 88). Jakarta: Gramedia Pustaka Utama. 2004.
} 
dimulai oleh Amerika Serikat sebagai pemilik senjata nuklir terbesar di dunia. Sebagai negara kecil, Korea Utara merasa masih terancam dari negara-negara di sekitarnya. Oleh karena itu, Korea Utara menghendaki jaminan keamanan dari Amerika Serikat melalui perundingan bilateral. Korea Utara berharap disepakatinya traktat non-agresi dengan Amerika Serikat. Amerika Serikat melihat kesedian Korea Utara berunding hanya sebagai taktik untuk mengulur waktu dalam mengembangkan program nuklirnya. Melihat kenyataan ini, kecil kemungkinan diplomasi akan benar-benar efektif sebagai instrumen penyelesaian masalah nuklir Korea Utara. Korea Utara tetap membutuhkan kepastian bahwa mereka aman dari agresi dan memperoleh jaminan bantuan kemanusian dan ekonomi. ${ }^{18}$

\section{Donald Trump dan Reorientasi Kebijakan Keamanan Amerika Serikat}

Menemukan cara untuk menyelesaikan masalah nuklir Korea Utara bukanlah hal yang mudah. Perdebatan panjang untuk menghentikan program nuklir Korea Utara telah dilakukan dalam upaya mencapai stabilisasi keamanan Semenanjung Korea. Pada prinsipnya, Trump mempuanyai lima opsi strategis dalam menghentikan program nuklir Korea Utara. ${ }^{19}$ Pertama, Trump hanya bersikap pasif dan mengikuti strategi yang sudah dijalankan oleh Presiden Amerika Serikat sebelumnya dan hanya menunggu respon dari Korea Utara untuk saling bersepakat dalam perjanjian denuklirisasi. Mengingat kegentingan yang terus muncul akibat ambisi nuklir Korea Utara, pilihan ini tampaknya tidak menjanjikan banyak keuntungan bagi Amerika Serikat. Bertentangan dengan apa yang diperkirakan banyak pengamat

\footnotetext{
${ }^{18}$ Sriyono, op. cit., p. 88.

${ }^{19}$ P. Jonathan, Donald Trump and the Future of U.S. Leadership: Some Observations on International Order, East Asia, and the Korean Peninsula. Makalah ini telah dipresentasikan pada 5th Korea Research Institute for National Strategy-Brookings Institution Joint Conference dengan tema "The Trump Administration in the United States and the Future of East Asia and the Korean Peninsula (pp. 813). 2017.
}

sebelumnya, saat Kim Jong-un menggantikan Kim Jong-ill, pemimpin Korea Utara itu kini telah berhasil mengkonsolidasikan posisinya dan pemerintahannya lebih stabil daripada rezim sebelumnya. ${ }^{20}$

Opsi kedua, Amerika Serikat menerapkan tindakan represif. Amerika Serikat dapat menekan rezim Korea Utara dengan tindakan non-militer, yakni dengan menggunakan sanksi, tekanan dan kebijakan isolasi yang dirancang untuk memberikan dampak yang lebih besar daripada yang selama ini sudah dilakukan kepada Korea Utara. ${ }^{21}$ Memperketat sanksi mungkin menjadi pilihan yang rasional, meski juga pilihan ini dianggap masih tidak menjanjikan hasil yang efektif, apabila tidak mengidentifikasi langsung sumber masalah nuklir Korea Utara. ${ }^{22}$ Opsi yang ketiga adalah mendorong Cina untuk memberikan tekanan ekonomi dan desakan politik kepada Korea Utara. Trump menyatakan bahwa Amerika Serikat harus terus menekan Cina untuk memanfaatkan kekuatan ekonominya atas Korea Utara sebagai tekanan untuk menyelesaikan permasalahan nuklir. Ketergantungan ekonomi Korea Utara terhadap Cina bisa menjadi kunci atas permasalahan nuklir. Pemerintahan Clinton, Bush dan Obama juga telah memahami kondisi ini, dan mereka berusaha melibatkan Beijing untuk terus berperan lebih aktif dalam kasus nuklir Korea Utara. ${ }^{23}$

Opsi keempat yang bisa dilakukan Amerika Serikat adalah menggunakan instrumen militer untuk menghentikan pengembangan senjata nuklir Korea Utara oleh rezim Korea Utara. Pendekatan ini menggunakan cara-cara ancaman secara langsung dan bertujuan untuk

\footnotetext{
${ }^{20}$ Ibid., pp. 8-13.

21 E.J.R. Revere, 2017: Year of Decision on the Korean Peninsula. Makalah ini telah dipresentasikan pada 5th Korea Research Institute for National Strategy-Brookings Institution Joint Conference dengan tema "The Trump Administration in the United States and the Future of East Asia and the Korean Peninsula (pp. 2-9). 2017.

${ }^{22}$ M. Liegl, The End of Illusions Trump's North Korea Options, Security Policy Working Paper no. 5, 3-4. 2017.

${ }^{23}$ Jonathan, op. cit., pp. 8-13.
} 
104 Muhammad Najeri Al Syahrin | Donald Trump dan Reorientasi Kebijakan Keamanan Amerika Serikat terhadap Program Pengembangan Senjata Nuklir Korea Utara

mengganti rezim Korea Utara. Donald Trump berulang kali menyatakan bahwa aksi militer melawan rezim Korea Utara dan program senjata nuklirnya sebagai skenario yang layak dilakukan oleh Amerika Serikat. Meskipun penggunaan kekuatan militer terhadap Korea Utara membawa risiko terjadinya perang. Perang akan menciptakan instabilitas keamanan, sosial, politik dan ekonomi yang tidak hanya dirasakan oleh negara-negara di kawasan saja tetapi juga negara-negara disekitar kawasan. Perang bisa memberikan dampak yang besar terhadap pasar uang dan aliran modal sehingga bisa memicu krisis ekonomi kawasan. Selain itu, opsi serangan militer pasti akan mengundang reaksi keras dari Cina yang tentu akan menyulitkan Amerika Serikat. Cina telah menjadi pesaing kuat bagi Amerika Serikat dan kini juga mulai berkembang menjadi negara adidaya baru, dan sebagaimana lazimnya negara adidaya, Cina juga akan bersikap tegas terhadap berbagai persoalan internasional khususnya yang terkait dengan keamanan. ${ }^{24}$

Mencoba opsi perundingan langsung dengan Pyongyang menjadi opsi kelima bagi pemerintahan Amerika Serikat. Trump telah mengumumkan niatnya untuk tidak menggunakan kembali strategi yang sudah digunakan presiden Amerika Serikat sebelumnya. Trump mengatakan, dia akan berbicara secara langsung dan membujuk pimpinan Korea Utara, Kim Jong-un, untuk menghentikan program nuklirnya. Jika Korea Utara kembali ke meja perundingan dan membuat konsesi bersama, Amerika Serikat harus mengatasi defisit keamanan rezim Korea Utara saat ini. Salah satu kemungkinan untuk melakukannya adalah dengan memenuhi permintaan Pyongyang untuk saling melaksanakan perjanjian damai di Semenanjung Korea. Tanpa diragukan lagi, kesimpulan dari kesepakatan ini akan menjadi perkembangan yang baik di kawasan, mengakhiri sikap bermusuhan negara pasti akan memperbaiki situasi kawasan secara keseluruhan. Berkenaan dengan isu nuklir, perjanjian damai tampaknya

\footnotetext{
${ }^{24}$ Courmont, op. cit., p. 4.
}

merupakan satu-satunya pilihan yang tepat bagi Amerika Serikat untuk mengatasi defisit keamanan rezim Korea Utara sebagai motif dasar program senjata nuklir dengan jaminan keamanan formal. Pyongyang telah mengumumkan kesediaannya untuk menghentikan pengujian nuklir jika Amerika Serikat menyetujui langkah ini. ${ }^{25}$ Mengingat kurangnya alternatif yang menjanjikan, Washington harus bisa memanfaatkan kesempatan ini.

Kelima pendekatan tersebut pada dasarnya sudah pernah dilakukan oleh presiden Amerika Serikat sebelumnya. Pada masa era Clinton, Bush dan Obama strategi dan pendekatan Amerika Serikat terhadap Korea Utara bersifat parsial. Artinya, antar satu kebijakan dengan kebijakan lainnya saling bertentangan dan tidak koheren. Padahal antar kebijakan dalam satu strategi seharusnya saling mendukung sehingga tercapai hasil akhir yang efektif. Pada masa pemerintahan Clinton, kemajuan signifikan pernah hampir dicapai Amerika Serikat. Kunjungan Menteri Luar Negeri Amerika Serikat, Madeleine K Albright ke Pyongyang pada November 2000 memungkinkan adanya kesepakatan rudal secara permanen disetujui jika Presiden Amerika Serikat melakukan kunjungan dan negosiasi langsung di Korea Utara. Ketika Presiden Clinton mendekati akhir masa jabatannya, waktu untuk mempersiapkan kunjungan tersebut menjadi semakin singkat. Sebaliknya, Korea Utara menegaskan bahwa kesepakatan rudal antara Amerika Serikat dan Korea Utara hanya dapat dicapai apabila Presiden Amerika Serikat melakukan kunjungan langsung ke Pyongyang. Namun Pada akhirnya, Amerika Serikat memutuskan untuk tidak mengambil risiko dalam kunjungan presiden tersebut. Kecurigaan ini pada akhirnya semakin menyulitkan

\footnotetext{
${ }^{25}$ AP, "North Korea offers to stop nuclear tests in exchange for peace treaty." The Telegraph. 2016. Diakses dari http://www.telegraph.co.uk/news/worldnews/asia/nor thkorea/12102995/North-Korea-offers-to-stopnuclear-tests-in-exchange-for-peace-treaty.html pada 23 Maret 2017.
} 
105 Muhammad Najeri Al Syahrin | Donald Trump dan Reorientasi Kebijakan Keamanan Amerika Serikat terhadap Program Pengembangan Senjata Nuklir Korea Utara

diplomasi dan upaya negosiasi Amerika Serikat pada masa-masa selanjutnya.

Hal yang sama kemudian terjadi pada masa pemerintahan Bush, ketika opsi negosiasi langsung dengan Korea Utara sudah terbentuk melalui kesepakatan kerja sama, maka upaya untuk memberikan sanksi sebaiknya tidak dilakukan. Paket kebijakan Amerika Serikat harus komprehensif mencerminkan adanya kesamaan komitmen sehingga memudahkan implementasi kesepakatan tersebut. Pada pertemuan putaran keempat perjanjian Six Party Talks yang dilaksanakan pada September 2005, terdapat beberapa perubahan positif yang idealnya terjadi pada proses denuklirisasi di Semenanjung Korea. Pertemuan tersebut menghasilkan kesepakatan bahwa Korea Utara setuju untuk menghentikan program nuklirnya dan kembali pada perjanjian non-proliferasi nuklir. Sebagai kompensasi atas kesepakatan tersebut, kelima negara lain dalam Six Party Talks akan menjamin keamanan serta normalisasi hubungan ekonomi dengan Korea Utara. Perjanjian ini telah membawa kesepakatan dan optimisme baru bagi hubungan Korea Utara dan Amerika Serikat. Namun pada akhirnya, Amerika Serikat tetap memberikan sanksi ekonomi terhadap Korea Utara. Hal ini membuat Korea Utara meragukan komitmen negara-negara dalam Six Party Talks dan memutuskan untuk tetap melaksanakan uji coba nuklir pada 9 Oktober $2006{ }^{26}$

Sedangkan pada era Obama, Amerika Serikat dinilai terlalu lembut dan cenderung pasif serta terlalu banyak berharap pada Cina untuk ikut serta secara bersama-sama menekan Pyongyang. Upaya ini pada akhirnya menghasilkan kesepakatan yang tidak efektif. Obama terlalu banyak berfokus pada Cina dan mengaburkan fokusnya secara langsung pada

\footnotetext{
${ }^{26}$ M. Hanson, Nuclear Weapons in the Asia Pacific: A Critical Security Appraisal. In Burke, A. \& McDonald, M (eds.), Critical Security in the Asia Pacific, (p.192). Manchester: Manchester University Press. 2007.
}

permasalahan Korea Utara. ${ }^{27}$ Berdasarkan pengalaman masa lalu dari kedua perundingan sebelumnya dan penolakan yang dilakukan Pyongyang dalam mematuhi kesepakatan dan komitmen yang telah dibuat, pilihan kebijakan "Strategic Patience" sebagai bagian dari strategi Poros Pasifik Obama tahun 2013 juga akhirnya tidak berhasil dalam mencapai target perlucutan senjata nuklir Korea Utara. ${ }^{28}$

Melihat keadaan tersebut dan semakin gentingnya permasalahan nuklir Korea Utara, Trump mencoba gaya kepemimpinan dengan kebijakan dan strategi yang berbeda. Perbedaan tersebut terlihat dari upaya Trump untuk menggabungkan semua strategi yang tersedia, selama berhasil menghentikan nuklir Korea Utara. Trump beberapa kali merubah strateginya dan mencoba berbagai cara untuk menghentikan nuklir Korea Utara. Pada dasarnya, Trump "tidak peduli" dengan cara apa dan dengan strategi apa kebijakan Amerika Serikat dilakukan, selama Korea Utara bersedia meninggalkan program nuklirnya maka strategi tersebut layak untuk dicoba. Perubahan kebijakan yang dilakukan oleh Donald Trump terlihat dari beberapa strategi kebijakan yang sudah direncanakan Trump sejak masa kampanye. Pada awal tahun 2017, pemerintahan Trump mencoba melakukan pendekatan militercentris dengan mengimplementasikan kebijakan keamanan yang menggunakan strategi kerja sama bilateral dan unilateral serta secara langsung menuntut biaya terhadap negara aliansinya atas kontribusi keamanan dari Amerika Serikat. Negara-negara di Asia Timur yang selama ini telah merasa aman dengan kehadiran kekuatan militer dalam beberapa dekade terakhir, kini merasakan situasinya sudah berubah. Negara sekutu di Asia Timur harus membayar biaya untuk kehadiran dan perlindungan keamanan Amerika Serikat di kawasan. Bagi Trump, Amerika Serikat

\footnotetext{
27 A. Ruggiero, Countering the North Korean Threat: New Steps in U.S. Policy. Congressional Testimony. Washington. Foundation for Defense of Democracy (pp. 4-8). 2017.

${ }^{28}$ Ibid., pp. 4-8.
} 
106 Muhammad Najeri Al Syahrin | Donald Trump dan Reorientasi Kebijakan Keamanan Amerika Serikat terhadap Program Pengembangan Senjata Nuklir Korea Utara

mengeluarkan biaya dan tanggung jawab militer yang sangat besar sehingga ia akan mengadakan perjanjian dengan posisi tawar yang lebih baik bagi Amerika Serikat.

Paradigma dan keyakinan Trump menyatakan bahwa Amerika Serikat mengabaikan keamanan sendiri dari ancaman eksternal jika mendukung keamanan negara lain. Kunci dasar kebijakan luar negeri ini adalah kalimat "Make America Great Again" dan "America First" yang menggaris bawahi kenyataan bahwa Amerika Serikat akan memperkuat kembali kekuatannya dalam bidang pertahanan dan kepentingan Amerika Serikat akan selalu menjadi prioritas utama. ${ }^{29} \mathrm{Hal}$ ini akan menyebabkan pergeseran postur kekuatan militer negara-negara di kawasan Asia Timur. Dalam konteks ini, tentu risiko geopolitik dan dilema keamanan akan meningkat dan memperburuk kondisi keamanan kawasan. Mengenai kebijakan nuklir, Trump juga telah memberikan saran terhadap Jepang dan Korea Selatan untuk juga mengembangkan senjata nuklir. Disisi yang lain, meskipun Trump juga telah mengecam senjata rudal balistik Amerika Serikat, namun pada kesempatan yang berbeda dia mengatakan bahwa Amerika Serikat akan meningkatkan anggaran belanja militernya guna mempercanggih sistem persenjataan. ${ }^{30}$

Ketika Korea Utara kembali melakukan berbagai uji coba rudal kendali dan secara langsung mengancam akan melakukan serangan atas markas militer Amerika Serikat di Guam pada pertengahan 2017. Hal ini kemudian menjadi sorotan bagi kegagalan Amerika Serikat untuk menghentikan ancaman keamanan dari Korea Utara. Amerika Serikat sudah sampai pada tahapan kritis terkait kebijakannya terhadap Korea Utara. Beberapa pengamat

\footnotetext{
${ }^{29}$ M. Overhaus \& L. Brozus, US Foreign Policy after the 2016 Elections. German Institute for International and Security Affairs 5, 2. 2016.

${ }^{30}$ M Makela, "Transcript: Donald Trump Expounds on His Foreign Policy Views." The New York Times. 2016.

Diakses

dari

https://www.nytimes.com/2016/03/27/us/politics/don ald-trump-transcript.html?mcubz $=1$ pada 29 April 2016.
}

berpendapat bahwa tidak realistis bagi Amerika Serikat untuk berkompromi dengan Korea Utara. Sehingga di harapkan pemerintahan Trump berfokus terhadap tantangan keamanan nasional lainnya. Namun, bahaya yang ditimbulkan oleh perkembangan nuklir Korea Utara amat besar khususnya terhadap mitra keamanan Amerika Serikat di kawasan sehingga ia tidak mungkin mengabaikan permasalahan ini. ${ }^{31}$

Trump mengemban tugas baru untuk membatasi ambisi nuklir Korea Utara tersebut, sesuatu yang telah gagal dilakukan para pemimpin Amerika Serikat sebelumnya. Pendekatan baru mutlak diperlukan untuk menghadapi tantangan nuklir Korea Utara. Selama ini hampir tidak ada prospek bahwa diplomasi, dialog, kerja sama, dan tekanan konvensional lainnya dapat meyakinkan Korea Utara untuk mengakhiri program senjata nuklirnya. Dialog bilateral, trilateral, multilateral dan resolusi Dewan Keamanan PBB, ditambah dengan sanksi ekonomi dan diplomatik, belum berjalan efektif untuk menghentikan ketegangan di kawasan Asia Timur akibat dari perkembangan nuklir Korea Utara. Upaya untuk melakukan denuklirisasi Korea Utara semuanya telah gagal dilakukan, dan pilihan kebijakan yang sudah dilakukan Pemerintahan Amerika Serikat juga gagal untuk menghentikan nuklir Korea Utara. Dengan demikian, sekarang saatnya mencoba sesuatu yang berbeda, jika ancaman yang ditimbulkan oleh nuklir Korea Utara lebih berbahaya daripada masa sebelumnya, maka pendekatan baru harus mencerminkan urgensi yang lebih besar. Trump harus mempertimbangkan untuk memaksa Korea Utara kembali ke meja perundingan denuklirisasi. Solusi diplomatik perlu dicoba sekali lagi untuk mencapai kesepakatan bersama. $^{32}$

Melihat kegentingan keamanan yang disebabkan oleh ujicoba nuklir dan peluru kendali Korea Utara, Trump kemudian secara

31 J. Wit, The Way Ahead: North Korea Policy Recommendations for the Trump Administration, US Korea Institute at Sais, Policy Brief, p. 24. 2016.

${ }^{32}$ Revere, op. cit., pp. 2-9. 
bijak beralih ke pendekatan yang lebih rasional yaitu strategi "Maximum Pressure and Engagement". Strategi ini menggabungkan antara retorika diplomatik, peningkatan sanksi dan perundingan. Melalui strategi ini, Trump berupaya mengkombinasikan solusi diplomatik dengan tindakan ekstrim dalam pemotongan sumber ekonomi, penghentian pasokan pangan dan diplomasi isolasi yang dapat memaksa Pyongyang untuk memilih antara pengembangan senjata nuklir atau kelangsungan hidupnya sebagai sebuah negara. Ketika pemimpin Korea Utara, Kim Jong Un merasa keberadaan rezimnya terancam, maka dia akan mempertimbangkan kembali opsi yang diberikan Amerika Serikat untuk melakukan perundingan denuklirisasi. ${ }^{33}$

Tujuan awal dari pendekatan ini adalah untuk membuat pemimpin Korea Utara menyadari bahwa mengejar kemampuan senjata nuklir akan mempengaruhi stabilitas dan kelangsungan hidup rezimnya. Amerika Serikat kemudian harus menjelaskan bahwa preferensi Washington adalah untuk melanjutkan dialog dengan Pyongyang dan berkomitmen untuk saling memperbaiki hubungan serta memberi Korea Utara bantuan ekonomi sebagai bagian dari kesepakatan denuklirisasi. Poin ini harus ditekankan dengan pemimpin Korea Utara jika ia menunjukkan minat pada dialog baru yang lebih serius. Washington harus bisa meyakinkan Kim Jong Un bahwa mereka siap untuk terlibat dalam mengatasi berbagai permasalahan Korea Utara, jika Pyongyang siap untuk membuka kembali dialog denuklirisasi. Pendekatan ini belum pernah dicoba sebelumnya, dan karena itu sulit untuk mengetahui apakah ini akan berhasil. Namun, tidak seperti pendekatan sebelumnya, ini menawarkan kesempatan untuk memaksa rezim Pyongyang untuk membuat pilihan strategis yang mendesak antara mengejar denuklirisasi atau mengambil risiko tentang keberlangsungan rezim. Jika pada akhirnya pendekatan ini tidak berhasil, tindakan yang sudah dilakukan akan tetap memberikan

\footnotetext{
${ }^{33}$ Ibid.
}

pengaruh besar terhadap stabilitas rezim Korea Utara. $^{34}$

Di sisi yang lain, Washington juga menyadari bahwa Pyongyang belum siap untuk negosiasi secara serius. Dengan demikian, strategi pertama bagi pemerintahan Trump adalah menekan rezim tersebut, dengan memotong sumber devisa, menghambat kegiatan ekonomi, dan menekannya secara militer. Pendekatan ini juga berusaha untuk mencari akar permasalahan pengembangan senjata nuklir Korea Utara, yaitu kelangsungan dan stabilitas rezim Kim di Korea Utara. ${ }^{35}$ Strategi ini melibatkan negara mitra di kawasan yaitu, Korea Selatan dan Jepang untuk ikut terlibat meyakinkan Kim Jong Un dalam menghentikan program nuklirnya. Inilah saatnya bagi Amerika Serikat dan negara aliansinya untuk saling secara bersama menekan Korea Utara agar kembali ke meja perundingan denuklirisasi.

Amerika Serikat akan memastikan bahwa Korea Utara akan kehilangan dan menderita kerugian jauh lebih banyak daripada yang akan diraihnya dengan terus mengejar kemampuan senjata nuklir. Hal ini jelas akan memerlukan analisa yang mendalam tentang pola tekanan sekaligus bujukan Amerika Serikat yang efektif. Amerika Serikat idealnya tidak secara serampangan mengeluarkan kebijakan dan pernyataan yang mengkhawatirkan bagi pemimpin Korea Utara. Washington harus tetap berada dalam komunikasi yang intens dengan Pyongyang dengan terus juga berupaya melakukan negosiasi formal sambil terus menyatakan kesedian untuk bertukar informasi dan pandangan terhadap bentuk kompensasi seperti apa yang paling ideal bagi Korea Utara. ${ }^{36}$

\footnotetext{
${ }^{34}$ Ibid.

${ }^{35}$ E.J.R. Revere, "The Trump Administration's North Korea Policy: Headed for Success or Failure." Brooking. 2017 Diakses dari https://www.brookings.edu/blog/order-fromchaos/2017/07/10/the-trump-administrations-northkorea-policy-headed-for-success-or-failure/ pada 15 September 2017.

${ }^{36}$ D. Straub, North Korea Policy: Recommendations for The Trump Administration. Academic Paper Series. Korea Economic Institute of America (pp 1-
} 
108 Muhammad Najeri Al Syahrin | Donald Trump dan Reorientasi Kebijakan Keamanan Amerika Serikat terhadap Program Pengembangan Senjata Nuklir Korea Utara

Selama ini, Korea Utara mengatakan bahwa senjata nuklir akan menjamin kelangsungan hidup rezim tersebut. Amerika Serikat harus meyakinkan Pyongyang untuk percaya bahwa pengembangan senjata nuklir akan menyebabkan kehancuran rezim tersebut. Korea Utara harus memilih antara pengembangan senjata nuklir dan keberlangsungan rezimnya. ${ }^{37}$ Hanya ketika pemimpin Korea Utara yakin bahwa ia mempertaruhkan akhir bagi rezimnya dengan mengejar kemampuan senjata nuklir, maka ia akan mempertimbangkan kembali perundingan yang diajukan Amerika Serikat.

Dalam upaya tersebut, sanksi terhadap Korea Utara harus diintensifkan ke dalam sektor ekonomi dan keuangan, termasuk perusahaan internasional yang selama ini berbisnis dengan Pyongyang. Harus terdapat kegiatan yang intens untuk memotong aliran pendapatan rezim Korea Utara. Aset Korea Utara harus disita jika terkait dengan aktivitas terlarang atau pelanggaran sanksi PBB. Sektor-sektor yang dijadikan sasaran adalah industri-industri skala besar seperti tekstil, perikanan, teknologi informasi dan manufaktur. ${ }^{38}$ Selama ini sanksi yang diberikan terhadap Korea Utara tidak untuk bertujuan "menghukum" Korea Utara tetapi hanya berperan sebagai diplomasi koersif saja, artinya Korea Utara tidak terlalu merasakan dampak signifikan terhadap sanksi yang diberikan dunia internasional. Dalam tahapan selanjutnya, Trump juga bisa memberikan sanksi lebih intensif supaya Korea Utara benar-benar merasakan dampaknya tidak hanya secara ekonomi tetapi juga secara politik. Tentu upaya ini tidak bisa terlepas dari peranan Cina. Langkah pertama bagi Trump sebaiknya juga bisa membawa dan membujuk Cina bersikap lebih kooperatif terhadap permasalahan nuklir

14). 2016.

${ }^{37}$ Revere, op. cit., pp. 2-9.; D. Straub, North Korea Policy: Recommendations for The Trump Administration. Academic Paper Series. Korea Economic Institute of America (pp 1-14). 2016.

38 "Presiden Trump Keluarkan Sanksi Baru Terhadap Korea Utara." BBC Indonesia. 2017 Diakses dari http://www.bbc.com/indonesia/dunia-41341015 pada 28 Oktober 2017.
Korea Utara. ${ }^{39}$ Untuk efektivitas pendekatan ini, Amerika Serikat juga harus bisa mendesak masyarakat internasional untuk menghentikan perdagangan dengan Korea Utara. Karena itulah koordinasi antara Amerika Serikat dengan Jepang dan Korea Selatan serta Cina akan menjadi lebih penting daripada sebelumnya jika pendekatan ini akan diterapkan. Rekomendasi dari strategi ini membawa beberapa risiko. Tapi membiarkan Korea Utara meningkatkan ancaman nuklirnya jauh lebih berisiko. ${ }^{40}$ Terdapat beberapa alasan strategi ini akan bekerja dengan maksimal karena paradoks kebijakan Korea Utara terhadap Amerika Serikat selama ini terletak dalam kebijakan ekonomi. Berbeda dengan kebijakan keamanan di mana Korea Utara sangat sulit untuk berunding dan menjalin kesepakatan dengan Amerika Serikat. Dalam bidang ekonomi, Korea Utara ingin menjalin kerja sama bilateral dengan Amerika Serikat dalam upaya stabilisasi ekonomi dalam negeri. Secara khusus, Korea Utara ingin agar Amerika Serikat mengeluarkan Korea Utara dari blacklist sistem ekonomi global agar ia bisa bergabung dengan institusi keuangan internasional guna mendapatkan akses modal asing dan pasar luar negeri. Selama terdapat sanksi ekonomi dari Amerika Serikat, sangat sulit bagi Korea Utara untuk mengembangkan kerja sama ekonomi maupun kerja sama di bidang lainnya, termasuk keamanan. ${ }^{41}$

Terbatasnya sumber daya yang dimiliki membuat Korea Utara sulit untuk mengembangan potensi ekonominya. Korea Utara terisolasi dari sistem internasional karena kebijakan rezim otoriternya yang melarang segala bentuk komunikasi dengan pihak luar. Hal ini kemudian diperparah dengan bencana alam dan kelaparan yang melanda negara tersebut. Rakyat Korea Utara hidup dengan banyaknya bantuan baik dari Cina, Rusia,

\footnotetext{
${ }^{39}$ P. Hayes \& C. Moon, The North Korean Nuclear Multilemma: Options to Break the Nuclear Deadlock in Northeast Asia, Institute of Korean Studies, 47, no. 4, pp. 699-719. (2016).

${ }^{40}$ Revere, op. cit., pp. 2-9.

${ }^{41}$ Pinkston, op. cit., pp. 23.
} 
109 Muhammad Najeri Al Syahrin | Donald Trump dan Reorientasi Kebijakan Keamanan Amerika Serikat terhadap Program Pengembangan Senjata Nuklir Korea Utara

Amerika Serikat, Jepang dan Korea Selatan. Bantuan-bantuan tersebut tidak hanya berupa pangan, tetapi juga energi, khususnya minyak. Walapun kondisi ekonominya sangat memprihatinkan dan sering mendapat bantuan dari dunia internasional, Korea Utara tampaknya akan tetap mengejar kepentingan nasionalnya untuk mencapai tujuan negara dengan ideologi yang telah ditentukan. ${ }^{42}$ Bagi Korea Utara, negosisasi terhadap program pengembangan senjata nuklir tidak akan berjalan efektif selama sanksi ekonomi Amerika Serikat terhadap Korea Utara tetap dilaksanakan.

\section{Kesimpulan}

Ketidakhadiran Amerika Serikat dalam upaya denuklirisasi Korea Utara akan menjadi preseden bahwa Amerika Serikat secara tidak langsung menyetujui apa yang sudah dilakukan Korea Utara sebagai pemilik negara nuklir. Bagaimana Trump akan mengelola isu ini akan menjadi kunci untuk menguji kredibilitas strategi dan efektivitas pendekatan keamanan Amerika Serikat secara umum. Trump harus berupaya untuk mengubah kebijakan keamanan Amerika Serikat secara drastis, karena kegagalan-kegagalan sebelumnya. Kegagalankegagalan tersebut seharusnya menjadi cerminan bagi kebijakan Amerika Serikat selanjutnya. Kepentingan Trump secara umum sama dengan kepentingan presiden Amerika Serikat sebelumnya, yaitu menghentikan program nuklir Korea Utara sebagai upaya untuk meredam tensi ketegangan di kawasan. Perbedaannya adalah cara dan pendekatan yang dilakukan. Dimasa lalu, kebijakan Amerika Serikat tidak koheren dengan strategi utama yang telah ditetapkan, sehingga antar kebijakan menjadi tidak komprehensif dan sinkron serta tidak saling mendukung, hal ini yang kemudian mengakibatkan banyak perjanjian dan kerja sama yang telah disepakati menjadi tidak efektif. Strategi yang kemudian diimplementasikan Trump dalam "Maximum Pressure and Engagement" berupaya merubah arah kebijakan (reorientasi) terhadap kebijakan yang selama ini sudah dilakukan presiden Amerika Serikat sebelumnya. Trump melakukan kombinasi strategi Hard Power Presiden Bush dan strategi Soft Power Presiden Obama menjadi kebijakan Smart Power. Dalam strategi smart power tersebut, Trump berupaya mengkombinasikan solusi diplomatik dan sanksi dengan tindakan ekstrim dalam pemotongan sumber ekonomi, penghentian pasokan pangan dan diplomasi isolasi. Bahkan, penggunaan instrumen militer juga sangat mungkin untuk dilakukan dalam memaksa Pyongyang menghentikan program pengembangan senjata nuklirnya. Apabila pendekatan yang dilakukan Amerika Serikat dibawah Trump, tidak berbeda dan lebih baik dengan yang selama ini sudah diterapkan, maka bisa dipastikan terdapat dua kemungkinan yang realistis. Korea Utara menjadi menjadi negara dengan kemampuan persenjataan nuklir yang stabil atau perang konvensional berskala besar terjadi di Semenanjung Korea.

\footnotetext{
${ }^{42}$ Pinkston, p. 23.
} 
110 Muhammad Najeri Al Syahrin | Donald Trump dan Reorientasi Kebijakan Keamanan Amerika Serikat terhadap

\section{Daftar Pustaka}

Armstrong, C.K., 2006, US-North Korean Relations, dalam J. Feffer (ed.), The Future of US-Korean Relations, Routledge, London

BBC Indonesia. 2017. Presiden Trump Keluarkan Sanksi Baru Terhadap Korea Utara. BBC Indonesia. Diakses dari http://www.bbc.com/indonesia/dunia41341015 pada 28 Oktober 2017.

China Economic Review. 2017. China's thirdquarter economic growth at $6.8 \%$. China Economic Review. Diakses dari http://www.chinaeconomicreview.com/chin as-third-quarter-economic-growth-68 pada 24 Oktober 2017.

Courmont, B., 2016. “Trump's Foreign Policy: Implications For Europe And East Asia, Iris: Institut De Relations Internationales Et Strategiques.

E.J.R. Revere, 2016. Brookings, https://www.brookings.edu/blog/order-fromchaos/2017/07/10/the-trumpadministrations-north-korea-policy-headedfor-success-or-failure/ diakses pada 15 September 2016.

E.J.R. Revere, 2017. 2017: Year of Decision on the Korean Peninsula, Korea Research Institute for National Strategy-Brookings Institution Joint Conference.

Hanson, M., 2007, Nuclear Weapons in the Asia Pacific: A Critical Security Appraisal. In Burke, A. \& McDonald, M (eds.), Critical Security in the Asia Pacific. Manchester University Press, Manchester.

Hayes, P. \& Moon, C. 2016. The North Korean Nuclear Multilemma: Options to Break the Nuclear Deadlock in Northeast Asia, Institute of Korean Studies, vol. 47, no. 4.
Holland, A. 2017. China's One Belt, One Road: An Ambitious Strategy Challenging the U.S. American Security Project. Diakses dari https://www.americansecurityproject.org/chi nas-one-belt-one-road-an-ambitiousstrategy-challenging-the-u-s/ pada 25 Oktober 2017.

Lanteigne, M., 2016. A Pivot to What? AsiaPacific Foreign Policy under Trump Policy Brief, Norwegian Institute of International Affairs.

Makela, M. 2016. Transcript: Donald Trump Expounds on His Foreign Policy Views. The New York Times. Diakses dari https://www.nytimes.com/2016/03/27/us/pol itics/donald-trump transcript.html?mcubz=1 pada 29 April 2016.

Max Fisher, 2016. 'What Is Donald Trump's Foreign Policy?' The New York Times, http://www.nytimes.com/2016/11/12/world/ whatis-donald-trumps-foreign-policy.html diakses pada 11 November 2016.

Moore, G.J., 2008. 'America's Failed North Korea Nuclear Policy: A New Approach,' Asian Perspective, vol. 32, no. 4.

Overhaus, M. \& Brozus, L., 2016. US Foreign Policy after the 2016 Elections, German Institute for International and Security Affairs.

Pinkston, D.A., 2006. 'North Korea's Foreign Policy Towards the United States,' Strategic Insights, vol. 5, no. 7.

Pollack, J. D., 2017, Donald Trump and the Future of U.S. Leadership: Some Observations on International Order, East Asia, and the Korean Peninsula.

Pritchard, T., 2010, U.S. Policy Toward the Korean Peninsula, Council on Foreign Relations, New York. 
111 Muhammad Najeri Al Syahrin | Donald Trump dan Reorientasi Kebijakan Keamanan Amerika Serikat terhadap Program Pengembangan Senjata Nuklir Korea Utara

Ruggiero, A. 2017. Countering the North Korean Threat: New Steps in U.S. Policy. Congressional Testimony. Washington. Foundation for Defense of Democracy.

Sriyono, A.A., 2004, Korea Utara: Antara Diplomasi dan Perang, dalam A.A. Sriyono, dkk, (ed) Hubungan Internasional: Percikan Pemikiran Diplomat Indonesia, Gramedia Pustaka Utama, Jakarta.

Straub, D. 2016. North Korea Policy: Recommendations for The Trump Administration. Academic Paper Series. Korea Economic Institute of America.

Sturm, P. 2017. Opinion: Unlike Donald Trump, North Korea has a plan. Deutsche Welle. Diakses dari $<$ http://www.dw.com/en/opinion-unlikedonald-trump-north-korea-has-a-plan/a40059106> pada 23 Oktober 2017.

The New York Times, 2016. "Transcript: Donald Trump Expounds on His Foreign Policy Views", https://www.nytimes.com/2016/03/27/us/p olitics/donald-trump-

transcript.html?mcubz=1 di akses pada 29 April 2016.

The Telegraph. 2017. North Korea offers to stop nuclear tests in exchange for peace treaty http://www.telegraph.co.uk/news/worldnew s/asia/northkorea/12102995/North-Koreaoffers-to-stop-nuclear-tests-in-exchangefor-peace-treaty.html, diakses pada 16 Maret 2017.

Ward, A. 2017. The frightening new developments in Trump's standoff with North Korea. Vox. Diakses dari https://www.vox.com/world/2017/8/1/1606 8716/north-korea-icbm-missile-testbomber-south-korea-japan pada 24 Oktober 2017.
Wirengjurit, D., 2002, Kawasan Damai dan Bebas Senjata Nuklir: Pengertian, Sejarah, dan Perkembangannya, Alumni, Bandung.

Wit, J. S., 2016. The Way Ahead: North Korea Policy Recommendations for the Trump Administration, US Korea Institute at Sais.

Yuliantoro, N. Rachmat., 2012, Menuju Kekuatan Utama Dunia: Sekilas Politik Luar Negeri Cina, Institute of International Studies, Yogyakarta. 